\title{
Preparation of injectable 3D-formed $\beta$-tricalcium phosphate bead/alginate composite for bone tissue engineering
}

Tomonori MATSUNO ${ }^{1}$, Yoshiya HASHIMOTO ${ }^{2}$, Seita ADACHI ${ }^{2}$, Kazuhiko OMATA ${ }^{1,3}$, Yamauchi YOSHITAKA ${ }^{1}$, Yasuyuki OZEKI ${ }^{4}$, Yoshikazu UMEZU ${ }^{4}$, Yasuhiko TABATA ${ }^{3}$, Masaaki NAKAMURA ${ }^{2}$ and Tazuko SATOH ${ }^{1}$

\author{
${ }^{1}$ Department of Oral and Maxillofacial Surgery, School of Life Dentistry at Tokyo, The Nippon Dental University, 1-9-20 Fujimi, Chiyoda, Tokyo \\ 102-8159, Japan \\ ${ }^{2}$ Department of Biomaterials, Osaka Dental University, 8-1 Kuzuhahanazono-cho, Hirakata-shi, Osaka 573-1121, Japan \\ ${ }^{3}$ Department of Biomaterials, Field of Tissue Engineering, Institute for Frontier Medical Sciences, Kyoto University, 53 Kawahara-cho, Shogoin, \\ Sakyo-ku, Kyoto 606-8507, Japan \\ ${ }^{4}$ New Material Science Laboratory, Advance Ltd., 899-5 Kitahara-cho, Tokorozawa-shi, Saitama 359-0004, Japan \\ Corresponding author, Tomonori MATSUNO; E-mail: matsunot@tky.ndu.ac.jp
}

\begin{abstract}
A novel, injectable bone tissue engineering material was developed that consisted of $\beta$-tricalcium phosphate ( $\beta$-TCP) beads as the solid phase and alginate as the gel phase. To prepare the instantaneously formed composite scaffold, an aqueous calcium chloride solution was dried on the surface of $\beta$-TCP beads and crosslinked with an alginic acid sodium solution, thereby forming stable $\beta$-TCP beads and alginate gel which were injectable via a syringe. This biodegradable composite was a three-dimensional (3D) material that could be used as an injectable scaffold for bone tissue engineering. In particular, the composite with $2.0 \mathrm{wt} \%$ alginate concentration exhibited a compressive strength of $69 \mathrm{kPa}$ in dry conditions, which was significantly higher than that exhibited by $1.0 \mathrm{wt} \%$. Furthermore, mesenchymal stem cells (MSC) were 3Dcultured within the composite and then investigated for osteogenic markers. MSC-loaded composite was subjected to scanning electron microscope (SEM) examination and implanted subcutaneously for in vivo experiment. Results showed that the scaffold provided support for osteogenic differentiation. In light of the encouraging results obtained, this novel injectable composite material may be useful for bone tissue engineering.
\end{abstract}

Key words: $\beta$-tricalcium phosphate $(\beta$-TCP) beads, Alginate, Injectable scaffold

Received Mar 2, 2008: Accepted Jun 11, 2008

\section{INTRODUCTION}

Autologous bone graft is the treatment of choice for filling large bone defects. However, this approach has some disadvantages, such as the need for a second surgery at the donor site, limited quantity and shape of available bone, and resorption of the bone graft ${ }^{11}$. In a bid to overcome these problems, bone tissue engineering has been promoted as a new way to regenerate bone tissue. This approach combines cells capable of osteogenetic activity with an appropriate scaffolding material to stimulate bone regeneration and repair ${ }^{2}$. In particular, cells such as mesenchymal stem cells (MSCs) have a high proliferation capacity and multilineage potential. They can be differentiated into osteoblasts ${ }^{3)}$ and thus have been used to engineer bone tissue ${ }^{4}$.

Furthermore, minimally invasive treatments have been developed using an injectable system. Several injectable gels have been used to carry cells in order to engineer bone. Amongst which are collagen $^{5,6)}$, alginate ${ }^{7,8)}$, and fibrin ${ }^{9)}$ gels, but these substances cannot be molded to the shapes of the bone defects when injected in situ or that they cannot follow the shapes of $3 \mathrm{D}$ cell culture molds in vitro.
Alginate has many uses in bioengineering, such as in polymer films, cell encapsulation, wound dressings, and surgical sponges ${ }^{10-12)}$. Alginic acid is soluble in water and can be ionically crosslinked with a non-toxic divalent cation solution, such as calcium chloride ${ }^{13)}$. The calcium ions bind the guluronic acid sites of alginate strands together to form a stable alginate gel ${ }^{14)}$. However, alginate lacks the initial mechanical strength needed for bone tissue engineering.

$\beta$-tricalcium phosphate $(\beta$-TCP) is a synthetic calcium phosphate ceramic used as an alternative autologous bone graft. It has been reported that $\beta$ TCP has good biodegradability and osteoconductivity as a scaffold material for bone tissue engineering ${ }^{15,16)}$. With regard to shape availability, both block and granular forms are available. However, both shapes pose an injectability problem and are difficult to be molded into a $3 \mathrm{D}$ structure.

In this study, a biodegradable composite of alginate loaded with MSCs and $\beta$-TCP beads was prepared. The injectable scaffold for bone regeneration was formed instantaneously from $\beta$ TCP beads and alginate. To the end of evaluating the mechanical stability and biocompatibility of this 
material, enzyme-linked immunosorbent assay (ELISA), real-time polymer chain reaction (RT-PCR), and SEM in vitro were employed. Additionally, in vivo osteoinductive effect was illustrated using an injectable composite loaded with non-osteogenicdifferentiated MSCs.

\section{MATERIALS AND METHODS}

Preparation of $\beta-T C P$ beads

In the present study, the $\beta$-TCP beads were prepared in a manner similar to a previously described method ${ }^{17-19)}$. An aqueous slurry of $\beta$-TCP powder (Advance Ltd., Saitama, Japan) and polyvinyl alcohol (Shin-Etsu Chemical Co. Ltd., Tokyo, Japan) aqueous solution as a binder reagent were mixed using an ultrasonic homogenizer. The resultant slurry was added drop-by-drop to liquid nitrogen, whereby slurry drops were frozen, and the frozen beads were freeze-dried. The beads were then sintered at $1100^{\circ} \mathrm{C}$ for 10 hours. Diameter of the beads was controlled at $100-1,000 \mu \mathrm{m}$ by regulating the opening and shutting times of an electromagnetic valve. Finally, microstructure of the resultant beads was observed using a scanning electron microscope (SEM; S-450, Hitachi Ltd., Tokyo, Japan), while crystallinity was characterized by X-ray diffraction (XRD) using an X-ray diffractometer (XD-3A, Shimadzu Ltd., Kyoto, Japan).

\section{Preparation of 3D-formed composite scaffold}

Alginate hydrogel was made by dissolving alginic acid sodium (Protanal LF 10/60, FMC BioPolymer, PA, USA) in phosphate-buffer saline (PBS) to give two final concentrations of 1.0 and $2.0 \mathrm{wt} \%$. The $\beta$ TCP beads, with a diameter of $710-850 \mu \mathrm{m}$, were dipped in $1.0 \% \mathrm{CaCl}_{2}$ solution (Sigma-Aldrich Co.) and then dried. $\beta$-TCP beads in the syringe were sterilized with ethylenoxide gas and alginate hydrogel with Stericup ${ }^{\circledR}(0.22 \mu \mathrm{m}$; Millipore Co., MA, USA). As alginate hydrogel was pushed out from the tip of the syringe, it passed through the $\mathrm{CaCl}_{2}$ treated $\beta$-TCP beads and instantaneous crosslinking occurred in the syringe. Once pushed out, the product was an injectable 3D composite scaffold.

\section{Morphological observation}

The composite scaffold was cut with a razor blade, and its microstructure observed by SEM (TM-1000, Hitachi Ltd., Tokyo, Japan) at $15 \mathrm{kV}$. Subsequently, an osteogenic differentiated MSC-loaded composite was fixed in glutaraldehyde, stained with platinum blue, and observed by SEM.

\section{Mechanical strength measurement}

Samples of the two types of composites were molded into syringes (1.0 and $2.0 \mathrm{wt} \%$ alginate hydrogels;
$5.0 \mathrm{~mm}$ in diameter and $10.0 \mathrm{~mm}$ in length). Compression test were carried out at room temperature on a universal testing machine (SV-301, IMADA, Aichi, Japan) at a crosshead speed of 0.5 $\mathrm{mm} / \mathrm{min}$. Compression modulus was calculated from the initial slope of the linear portion of the stressstrain curve. The experiment was performed for four samples per composite - and by the same person in the same setting for all samples.

Mesenchymal stem cell seeding and $3 D$ culture in composite

Human MSCs were obtained from RIKEN Cell Bank (Tsukuba, Japan) $^{20)}$ and maintained in continuous culture at $37^{\circ} \mathrm{C}$ in a $5 \% \mathrm{CO}_{2}$ humidified atmosphere. MSCs were expanded for 7-10 days in DMEM supplemented with 10\% heat-inactivated FBS, $3 \mathrm{ng} /$ $\mathrm{ml}$ fibroblast growth factor-2, and 1\% antibiotic/ antimycotic in $75 \mathrm{~mm}^{2}$ flasks. After a sufficient number of MSCs was obtained, they were dispersed into the alginate hydrogel. Following which, MSCloaded alginate hydrogel was added into the syringe which was packed with $\mathrm{CaCl}_{2}$-treated beads. Consequently, MSC-loaded alginate was crosslinked and MSCs were loaded into the $3 \mathrm{D}$ scaffold at about $2 \times 10^{5}$ cells/scaffold. They were cultured in an osteogenic differentiation medium $(10 \mathrm{mM} \quad \beta$ glycerophosphate, $100 \mathrm{nM}$ dexamethasone, and 50 $\mu \mathrm{g} / \mathrm{ml}$ ascorbic acid) for 1,7 , and 14 days.

\section{Alkaline phosphatase (ALP) activity}

MSC-loaded composite was washed twice with PBS. The lysates obtained from the composite were homogenized in $10 \mathrm{mM}$ Tris ( $\mathrm{pH}$ 7.4) using a mixer mill (Retsch MM301, Retsch GmbH, Haan, Germany). A colorimetric assay was performed to ascertain the total protein content. Briefly, prior to the analysis, half of the lysates was adjusted for protein quantification (Protein Quantification Kit-Rapid, Dojindo Laboratories, Kumamoto, Japan). Absorbance was quantified at $595 \mathrm{~nm}$ using a microplate reader (Model 680, Bio-Rad Laboratories, CA, USA). The remaining half of the lysates was used for ALP activity measurement using LabAssay ${ }^{\mathrm{TM}}$ ALP (Wako Pure Chemical Industries Ltd., Osaka, Japan), where $p$-nitrophenylphosphate was employed as a substrate. Released $p$-nitrophenol was optically measured at $405 \mathrm{~nm}$ as the enzyme activity. The amount of ALP activity was normalized by the total protein content in the lysates.

\section{$m R N A$ expression levels of osteocalcine (OCN)}

Total RNA was isolated from the cell cultures, and single-strand cDNA was synthesized using a High Capacity cDNA Reverse Transcription Kit (Applied Biosystems, CA, USA). OCN mRNA expression levels were analyzed by the quantitative RT-PCR 
method using TaqMan ${ }^{\circledR}$ Gene Expression Assays (Applied Biosystems, CA, USA) on an ABI Prism ${ }^{\circledR}$ 7700 Sequence Detection System (Applied Biosystems, CA, USA). The GAPDH gene was complified as an internal standard.

\section{In vivo implantation}

Non-osteogenic-differentiated MSCs loaded into the $3 \mathrm{D}$ composite scaffold $\left(5 \times 10^{6}\right.$ cells $/$ scaffold $)$ and MSC-free composite as control were subcutaneously implanted into the backs of 6 -week-old KSN nude mice. All animal experiments were performed in accordance with the Guidelines for Animal Experiments (Osaka Dental University, 2006). The mice were killed at 8 weeks after implantation. Tissue blocks were removed and fixed in 10\% (v/v) buffered formalin. After decalcification and paraffin embedding, blocks were vertically sectioned and subjected to hematoxylin and eosin (H\&E) staining for histological examination.

\section{Statistical analysis}

All values were expressed as mean value \pm standard deviation of the mean (SD). Statistical analysis was performed using Student's t-test and one-way ANOVA. $\quad \mathrm{P}<0.05$ was considered to be statistically significant.

\section{RESULTS}

Morphology and mechanical strength of the composite Figure 1 shows the SEM photographs of $\beta$-TCP bead and the surface of the bead. Diameter of the bead was about $500 \mu \mathrm{m}$, and micropores were observed on the surface.

Figure 2 shows the XRD patterns of the synthesized $\beta$-TCP beads and commercially available $\beta$-TCP (OSferion ${ }^{\circledR}$; Olympus, Tokyo, Japan). There were no significant differences in the intensity of $\beta$ TCP peaks between $\beta$-TCP beads and commercially available $\beta$-TCP.

Figure 3 shows a photograph of injectable 3Dformed composite of $\beta$-TCP beads and alginate and a light microscope photograph of the composite. As soon as alginate hydrogel was pushed out from the tip of the syringe, a 3D-formed composite of $\beta$-TCP beads and alginate was obtained due to the instantaneous crosslinking that occurred in the syringe.

Figure 4 shows the microstructure of the instantaneously formed composite. Each bead was wrapped in the anastomosing network of the alginate gel, and the beads were bonded tightly to form a 3D structure (Fig. 4A). Minute crystal projections were observed on the cross-sectional surface of the $\beta$-TCP beads treated with $\mathrm{CaCl}_{2}$ (Fig. 4B).

Figure 5 shows the compression moduli of the two types of composites. It is clearly shown that

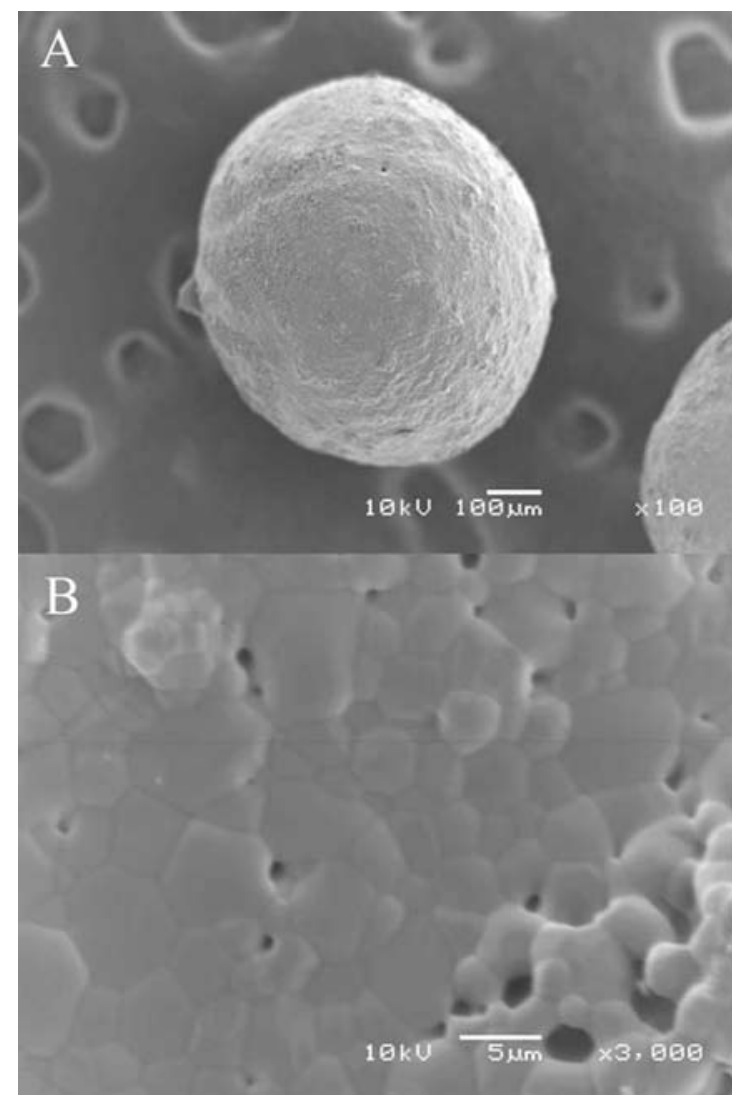

Fig. 1 SEM photographs of a $\beta$-TCP bead (A) and the surface of the bead (B). Bar is $100 \mu \mathrm{m}$ in (A) and $5 \mu \mathrm{m}$ in (B).

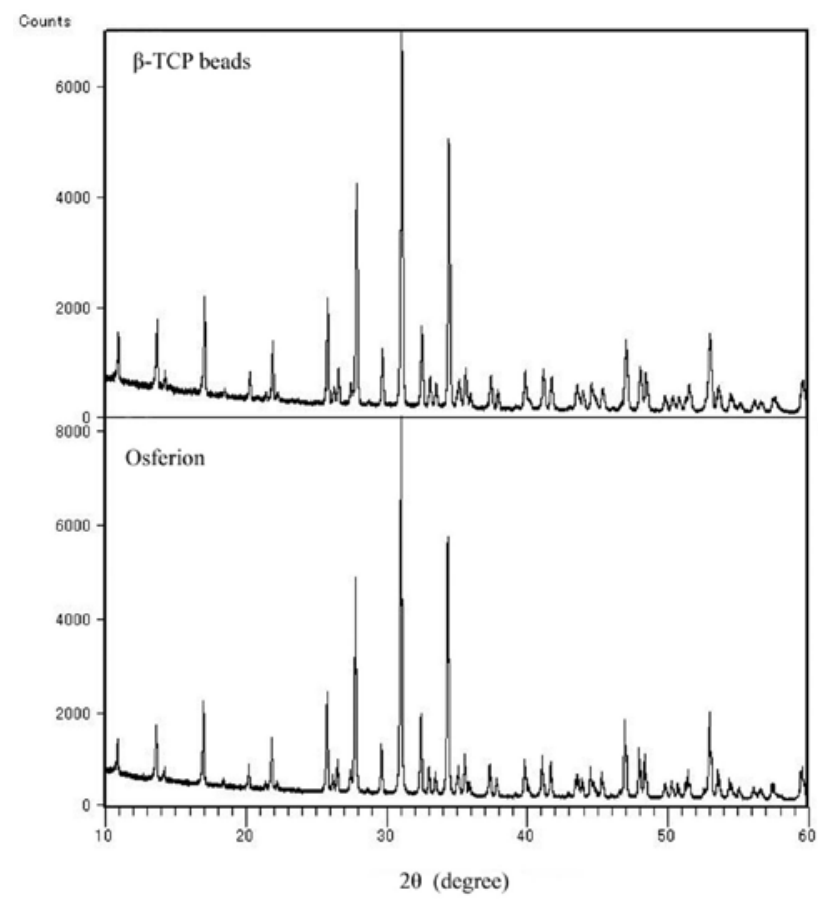

Fig. 2 X-ray diffraction patterns of synthesized $\beta$-TCP beads and commercially available $\beta$-TCP. 


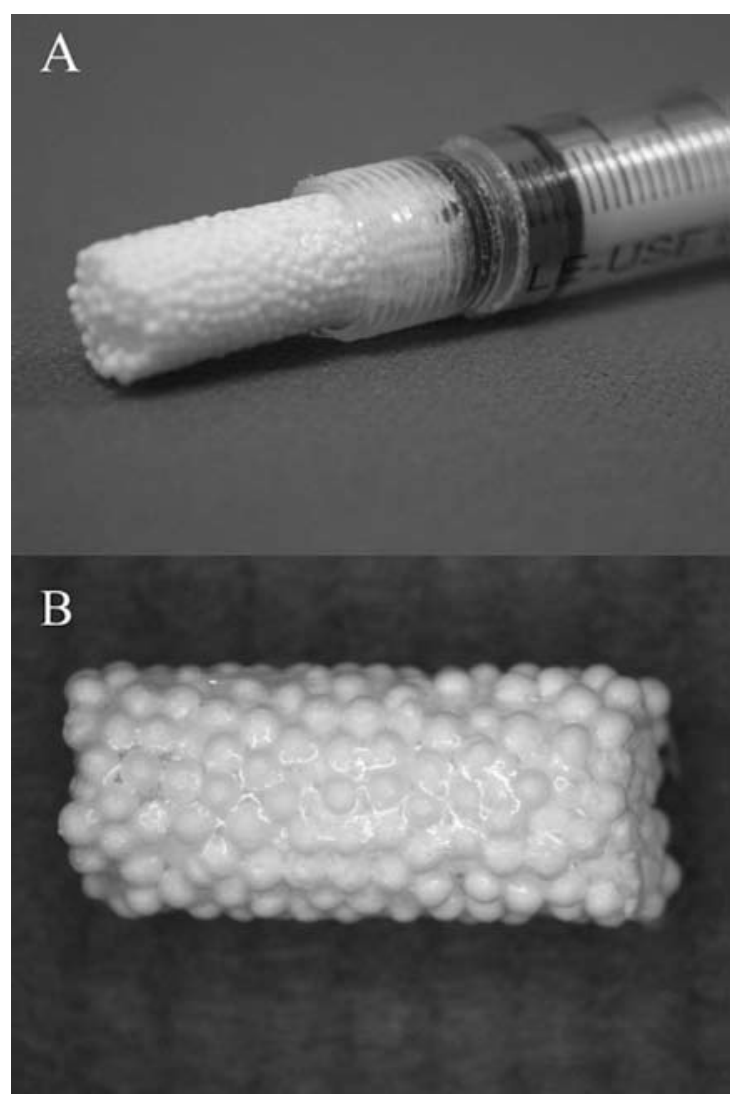

Fig. 3 Photograph of injectable 3D-formed composite of $\beta$-TCP beads and alginate (A) and light microscope photograph of the composite (B).

compressive strength increased with increased alginate concentration. The composite of $2.0 \mathrm{wt} \%$ alginate concentration exhibited a compressive strength of $69.0 \pm 4.6 \mathrm{kPa}$, which was significantly greater $(\mathrm{P}<0.05)$ than the strength seen with 1.0 wt\% $(6.11 \pm 2.28 \mathrm{kPa})$.

\section{In vitro differentiation}

Figure 6 shows the SEM photographs of MSC-loaded composite after 1 day and 14 days in the osteogenic differentiation culture. MSCs were observed in the composite at day 1 (Fig. 6A). After 14 days, many calcified nodules appeared on the surface of $\beta$-TCP beads and alginate (Fig. $6 \mathrm{~B}$ ).

Figure 7 shows that the ALP activity of MSCs grown within the composite of osteogenic differentiation culture increased from day 1 to day 7 , but decreased from day 7 to day 14 . There was a significant increase between day 1 and day 7 , and similarly a significant decrease between day 7 and day $14(\mathrm{P}<0.05)$.

No OCN mRNA expression was detected at day 1. However, OCN mRNA expression increased from

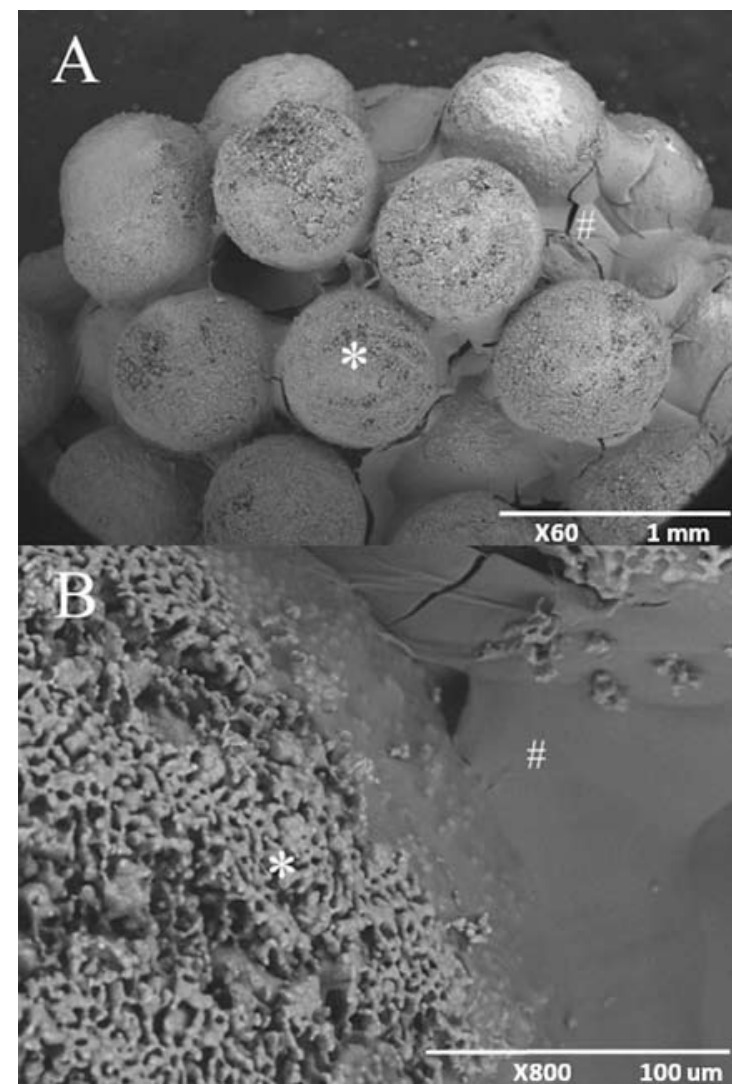

Fig. 4 SEM photographs of the composite (A) and surface of the composite (B). The composite was composed of $\beta$-TCP beads ( $*$ ) and alginate (\#). Bar is 1,000 $\mu \mathrm{m}$ in (A) and $100 \mu \mathrm{m}$ in (B).

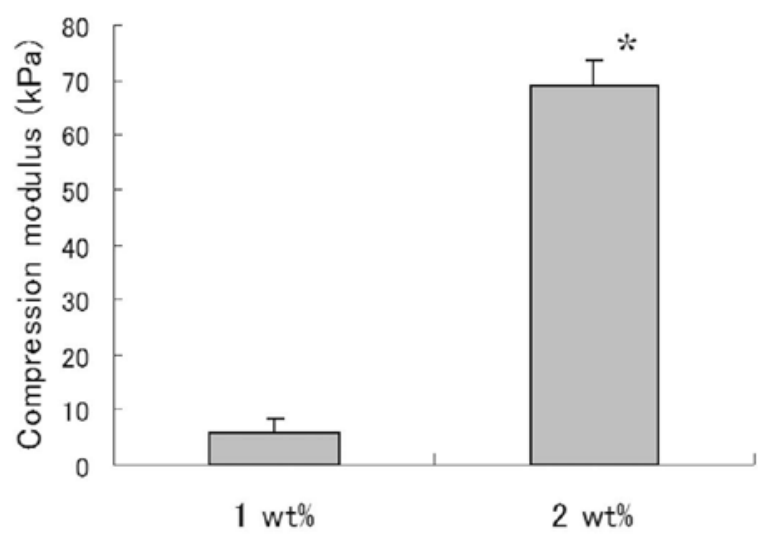

Fig. 5 Compression moduli of composites with 1.0 and $2.0 \mathrm{wt} \%$ alginate concentrations. $*: \mathrm{P}<0.05$, i.e., significant difference between 1.0 and $2.0 \mathrm{wt} \%$ alginate concentrations. 


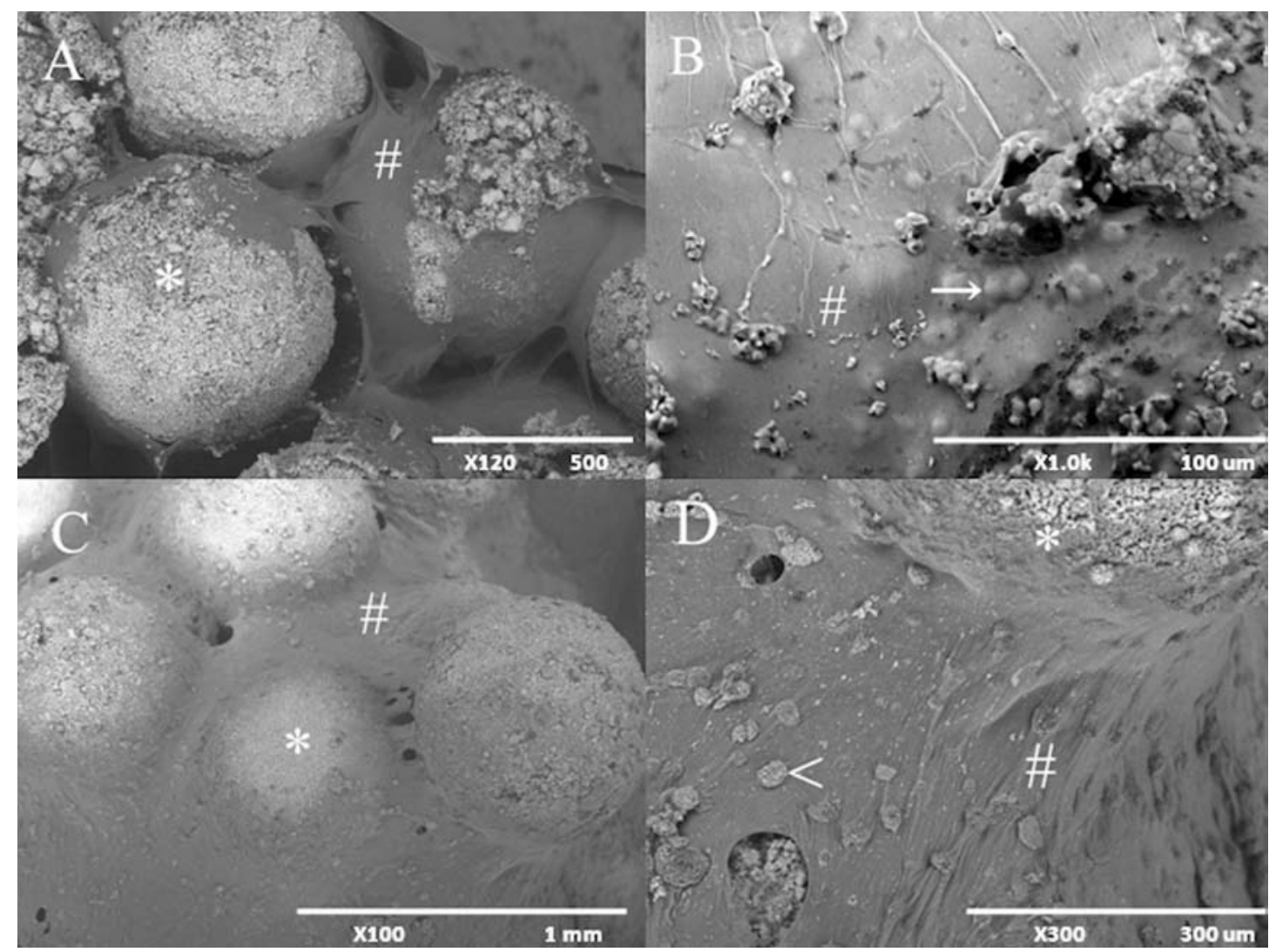

Fig. 6 SEM photographs of MSC-loaded composite at day 1 (A, B) and day 14 (C, D) in osteogenic differentiation culture. MSCs (arrow) were observed in the alginate (\#), and calcified nodules $(<)$ appeared on the composite surface. *: $\beta$-TCP beads. Bar is $500 \mu \mathrm{m}$ in (A), $100 \mu \mathrm{m}$ in (B), 1,000 $\mu \mathrm{m}$ in (C), and $300 \mu \mathrm{m}$ in (D).

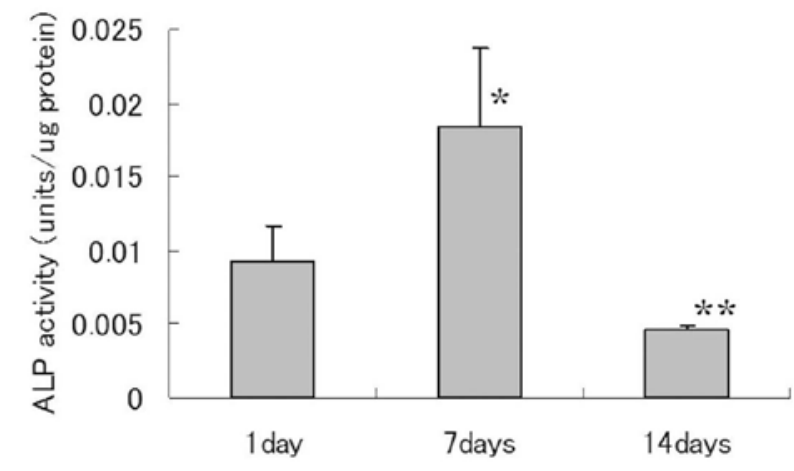

Fig. 7 ALP activity of MSCs grown within the composite after 1,7 , and 14 days in osteogenic differentiation culture. $\quad *$ : $\mathrm{P}<0.05$, i.e., significant increase between days 1 and $7 . \quad * *$ : $\mathrm{P}<0.05$, i.e., significant decrease between days 7 and 14 .

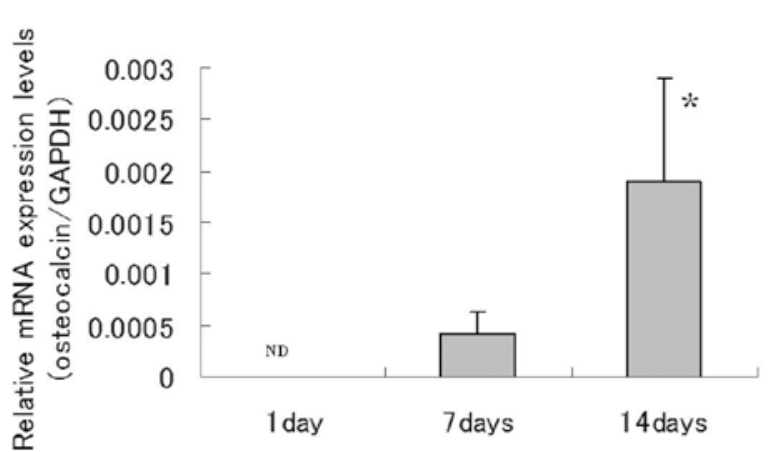

Fig. 8 OCN mRNA expression levels of MSCs grown within the composite at 1,7 , and 14 days in osteogenetic differentiation culture. ND: No mRNA expression was detected on day 1 . $*: \mathrm{P}<0.05$, i.e., significant increase between days 7 and 14 in culture. 


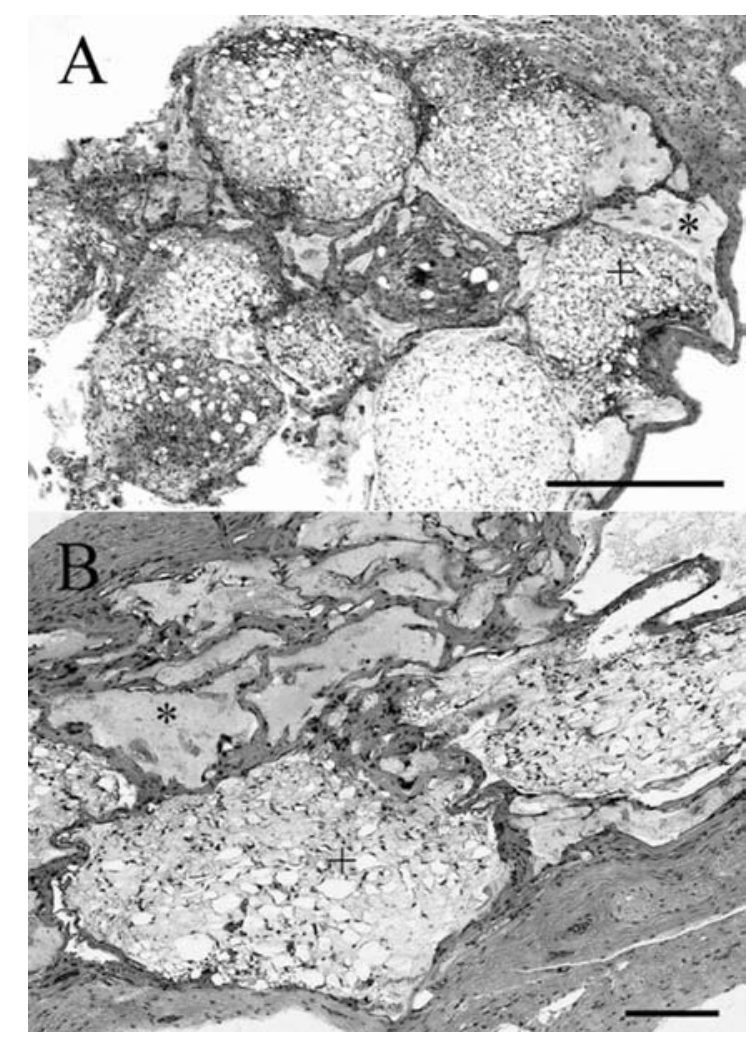

Fig. 9 H\&E-stained histological sections of 3D composite scaffold loaded with MSCs at 8 weeks after implantation. Newly formed, bone-like calcified tissue was observed on the surface of the $\beta$-TCP beads $(*)$ and in the connective tissue. A: $\times 10$, bar is $500 \mu \mathrm{m}$; B: $\times 20$, bar is $100 \mu \mathrm{m}$.

day 1 to day 7 , and increase between day 7 and day 14 was statistically significant $(\mathrm{P}<0.05)$ (Fig. 8).

\section{In vivo implantation}

Figure 9 shows the histological sections of the 3D composite scaffold loaded with non-osteogenicdifferentiated MSCs at 8 weeks after implantation. Newly formed, bone-like calcified tissue was directly deposited on the surface of the $\beta$-TCP beads. Interconnected alginate was completely degraded, and bone-like calcified tissue was observed in the connective tissue. The surface of the $\beta$-TCP beads was slightly degraded and vacuolization was observed in the beads. On the other hand, cell-free composite contained only fibrovascular tissue around nondegraded $\beta$-TCP beads (data was not shown).

\section{DISCUSSION}

One tissue engineering approach for bone regeneration is to combine osteogenetic cells with an appropriate scaffold such as calcium phosphate ceramics. MSCs are promising candidates for use in bone tissue engineering because of their high proliferation rate and ability to differentiate into osteoblasts in culture. In keeping with the tissue engineering concept, cells are cultivated on 3D scaffolds to replace 3D tissue defects ${ }^{21}$. However, elaborate seeding and culture conditions are needed to achieve uniform cellular distribution, sustain cell viability, and provide nutrients for tissue formation in scaffolds ${ }^{22)}$.

$\beta$-TCP has been used for bone tissue engineering due to its good biocompatibility and biodegradability. However, it is difficult to fit into the surgical sites around implants or to be shaped to the desired forms using $\beta$-TCP blocks or granules. Recently, the increasing popularity of minimally invasive techniques has led to the development of an injectable system that can be molded to the shape of the bone defect and which polymerizes when injected into the $\operatorname{site}^{23)}$. Such devices should be easy to implant, thereby shortening the surgical time and minimizing the damage to healthy tissue.

In this study, alginate hydrogel was used to facilitate the delivery and distribution of MSCs in a scaffold made of $\beta$-TCP beads. Alginate hydrogel has been shown to be an appropriate substrate for suspended cells for more than six weeks ${ }^{24)}$; more importantly, it is able to promote bone formation by $\mathrm{MSC}^{25}$. Calcium ions can be crosslinked with the guluronic acid sites of alginate strands to form a stable alginate gel ${ }^{14)}$. Leveraging on all these properties in this study, an instantaneously formed, injectable $3 \mathrm{D}$ scaffold was obtained after alginate hydrogel reacted with $\mathrm{CaCl}_{2}$-coated $\beta$-TCP beads and then loaded with MSCs.

It has been previously demonstrated that alginate hydrogels induce bone formation in vitro ${ }^{22,26)}$. However, the lack of adequate initial strength of hydrogel/cell constructs requires additional mechanical support for implantation ${ }^{23)}$. Therefore, in this study, a uniform size of $\beta$-TCP beads was selected to reinforce the initial strength to the end of providing an elaborate 3D structure composed of hydrogel, beads and MSCs. SEM observation of the beads showed that the beads were almost spherical with pores surrounding them. It has been suggested that the degradation associated with TCP produces a localized calcium- and phosphorus-rich environment that may be more favourable for osteogenesis ${ }^{27,28)}$. Previous in vitro studies have shown that composite sponge of hydroxyapatite beads and poly (DL-lacticco-glycolic acid) $)^{17)}$ and bone graft sheets composed of $\beta$-TCP beads and MSCs and inserted with poly-Llactic acid sheet in between ${ }^{18)}$ all supported osteogenesis. Similarly, in vivo experiment on bone 
graft sheets composed of $\beta$-TCP beads and MSCs and combined with collagen gel ${ }^{19)}$ also yielded favorable result for osteogenesis.

Furthermore, this study showed that the concentration of alginate hydrogel played a major role in increasing the latter's resistance to compression. However, it must be highlighted that viscosity increases with alginate concentration in solution. High alginate concentrations can result in solutions becoming too viscous to be employed for the injection method $^{14)}$. For this reason, 1.0 and $2.0 \mathrm{wt} \%$ alginate concentrations were chosen in this study to evaluate the mechanical strength of the composites. Results showed that $2.0 \mathrm{wt} \%$ alginate concentration yielded a significantly greater strength than $1.0 \mathrm{wt} \%$ under dry conditions. However, the compressive strength of the composite with $2.0 \mathrm{wt} \%$ alginate concentration was too low for implantation into segmental bone defects. Nonetheless, it remains useful as a bone substitute material under load-bearing conditions such as augmentation of bone cavities, because the composite had adequate elasticity to be cut, shaped, and fitted into the implantation site.

On the ability of the composite to support osteogenesis, it was evaluated using 3D MSC differentiation culture. MSCs were used because of their high proliferation rate and ability to differentiate into osteocytes in culture ${ }^{3)}$ and in hydrogels ${ }^{29}$. Through SEM examination, MSCs were observed in the alginate of the composite after 1 day. However, bone-like nodules appeared at 14 days. In light of these results, it could thus be said that the composite is suitable for differentiation of MSCs in 3D culture. In addition, ALP activity at 7 days was significantly increased as compared to day 1 , but decreased from day 7 to day 14. As a marker of early osteogenic differentiation, the ALP activity of the construct was measured on days 1,7 , and 14 of the culture period. The typical rise and fall of ALP activity was characteristic of osteogenic differentiation and common to all culture systems ${ }^{31,32)}$. Furthermore, OCN mRNA expression, another marker of osteogenic differentiation, was significantly increased at day 14 as compared to day 7. Therefore, it is conceivable that calcification progressed in the composite.

In vivo experiment demonstrated that the $\beta$ TCP bead/alginate composite had an osteoinductive effect in soft tissue - without an osteogenic differentiation medium for MSCs. Similarly, Livingston et $a l .^{2}$ demonstrated that hydroxyapatite/ $\beta$-TCP ceramic scaffold promoted bone formation in soft tissue, which was induced by non-osteogenic-differentiated MSCs. Furthermore, this study demonstrated that $\beta$-TCP bead/alginate composite induced the formation of bone-like calcified tissue. Taken together, these results suggested that a $3 \mathrm{D}$ structure consisting of $\beta$-TCP beads and alginate allowed an appropriate spatial arrangement of osteogenic cells as well as vascular invasion. These findings also indicated that injectable $\beta$-TCP bead/alginate composites supported bone regeneration with a minimally invasive technique.

In conclusion, this study demonstrated that injectable composites fabricated from $\beta$-TCP beads and alginate were sufficiently adaptable to the irregularities of bone defects and which possessed adequate mechanical strength. Furthermore, the biodegradable $\beta$-TCP bead/alginate composite was replaced by bone without any adverse reactions. In light of the encouraging results obtained for osteogenesis, the novel composite developed in this study may be useful as an injectable scaffold for bone tissue engineering.

\section{ACKNOWLEDGEMENTS}

This study was supported in part by a grant from the $100^{\text {th }}$ Anniversary of the Foundation of the Nippon Dental University.

\section{REFERENCES}

1) Miyamoto $Y$, Ishikawa $K$, Takechi M, Toh T, Yuasa T, Nagayama M, Suzuki K. Basic properties of calcium phosphate cement containing atelocollagen in its liquid or powder phases. Biomaterials 1998; 19: 707-715.

2) Livingston Arinzeh T, Tran T, Mcalary J, Daculsi G. A comparative study of biphasic calcium phosphate ceramics for human mesenchymal stem cell-induced bone formation. Biomaterials 2005; 26: 3631-3638.

3) Pittenger MF, Mackay AM, Beck SC, Jaiswal RK, Douglas R, Mosca JD, Moorman MA, Simonetti DW, Craig S, Marshak DR. Multilineage potential of adult human mesenchymal stem cell. Science 1999; 284: 143-147.

4) Petite H, Viateau V, Bensaid W, Meunier A, de Pollak C, Bourguignon M, Oudina K, Sedel L, Guillemin G. Tissue-engineered bone regeneration. Nat Biotechnol 2000; 18: 959-963.

5) Tsuchida H, Hashimoto J, Crawford E, Manske P, Lou J. Engineered allogeneic mesenchymal stem cells repair femoral segmental defect in rats. J Orthop Res 2003; 21: 44-53.

6) Riew KD, Wright NM, Cheng S, Avioli LV, Lou J. Induction of bone formation using a recombinant adenoviral vector carrying the human BMP-2 gene in a rabbit spinal fusion model. Calcif Tissue Int 1998; 63: 357-360.

7) Shang Q, Wang Z, Liu W, Shi Y, Cui L, Cao Y. Tissue-engineered bone repair of sheep cranial defects with autologous bone marrow stromal cells. J Craniofac Surg 2001; 12: 586-593.

8) Wang L, Shelton RM, Cooper PR, Lawson M, Triffitt JT, Barralet JE. Evaluation of sodium alginate for bone marrow cell tissue engineering. Biomaterials 2003; 24: 3475-3481.

9) Perka C, Arnold U, Spitzer RS Lindenhayn K. The 
use of fibrin beads for tissue engineering and subsequential transplantation. Tissue Eng 2001; 7: 359-361.

10) De Vos P, De Haan BJ, Wolters GHJ, Strubbe JH, Van Schilfgaarde R. Improved biocompatibility but limited graft survival after purification of alginate for microencapsulation of pancreatic islets. Diabetologia 1997; 40: 262-270.

11) Klöck G, Frank H, Houben R, Zekorn T, Horcher A, Siebers U, Wöhrle M, Federlin K, Zimmermann U. Production of purified alginates suitable for use in immunoisolated transplantation. Appl Microbiol Biotechnol 1994; 40: 638-643.

12) Matthew IR, Browne RM, Frame JW, Millar BG. Subperiosteal behavior of alginate and cellulose wound dressing materials. Biomaterials 1997; 18: 707-713.

13) De Vos P, De Haan B, Van Schilfgaarde R. Effect of the alginate composition on the biocompatibility of alginate-polylysine microcapsules. Biomaterials 1997; 18: 273-278.

14) Becker TA, Kipke DR, Brandon T. Calcium alginate gel: A biocompatible and mechanically stable polymer for endovascular embolization. J Biomed Mater Res 2001: 54: 76-86.

15) Le Geros RZ. Properties of osteoconductive biomaterials: calcium phosphates. Clin Orthop Relat Res 2002; 395: 81-98.

16) Matsuno $T$, Nakamura $T$, Kuremoto $K$, Notazawa $S$, Nakahara T, Hashimoto Y, Satoh T, Shimizu Y. Development of $\beta$-tricalcium phosphate/collagen sponge composite for bone tissue regeneration. Dent Mater J 2006; 25: 138-144.

17) Ushida T, Chen G, Tamaki T, Umezu Y, Tateishi T. A three-dimensional porous scaffold of biodegradable synthetic polymers and porous hydroxyapatite beads for bone tissue engineering. Bioceramics 2001; 13: 519-522.

18) Furukawa KS, Miyauchi S, Suzuki D, Umezu Y, Shinjo T, Ushida T, Eguchi M, Tateishi T. Bone tissue engineering based on bead-cell sheets composed of calcium phosphate beads and bone marrow cells. Mater Sci Eng C 2004; 24: 437-440.

19) Miyauchi S, Furukawa KS, Umezu Y, Ozeki Y, Ushida T, Tateishi T. Novel bone graft model using bead-cell sheets composed of tricalcium phosphate beads and bone marrow cells. Mater Sci Eng C 2004; 24: 875-879.

20) Tsutsumi S, Shimazu A, Miyazaki K, Pan H, Koike C, Yoshida E, Takagishi K, Kato Y. Retention of multilineage differentiation potential of mesenchymal cells during proliferation in response to FGF. Biochem Biophys Res Commun 2001; 288:
413-418.

21) Liu H, Li H, Cheng W, Yang Y, Zhu M, Zhou C. Novel injectable calcium phosphate/chitosan composites for bone substitute materials. Acta Biomater 2006; 2: 557-565.

22) Weinand C, Pomerantseva I, Neville CM, Gupta R, Weinberg E, Madisch I, Shapiro F, Abukawa H, Troulis MJ, Vacanti JP. Hydrogel- $\beta$-TCP scaffolds and stem cells for tissue engineering bone. Bone 2006; 38: 555-563.

23) Niemeyer P, Krause U, Fellenberg J, Kasten P, Seckinger A, Ho AD, Simank HG. Evaluation of mineralized collagen and $\boldsymbol{\alpha}$-tricalcium phosphate as scaffolds for tissue engineering of bone using human mesenchymal stem cells. Cells Tissue Organs 2004; 177: 68-78.

24) Chung TW, Yang J, Akaike T, Cho KY, Nah JW, Kim SI, Cho CS. Preparation of alginate/galactosylated chitosan scaffold for hepatocyte attachment. Biomaterials 2002; 23: 2827-2834.

25) Lawson MA, Barralet JE, Wang L, Shelton RM, Triffitt JT. Adhesion and growth of bone marrow stromal cells on modified alginate hydrogels. Tissue Eng 2004; 10: 1480-1491.

26) Alsberg E, Anderson KW, Albeiruti A, Franceschi RT, Moony DJ. Cell-interactive alginate hydrogels for bone tissue engineering. J Dent Res 2001; 80: 2025-2029.

27) Yuan H, Zou P, Yang Z, Zhang X, de Bruijn JD, de Groot K. Bone morphogenetic protein and ceramicinduced osteogenesis. J Mater Sci: Mater Med 1998; 9: 717-721.

28) Frayssinet P, Trouillet JL, Rouquet N, Azimus E, Autefage A. Osseointegration of macroporous calcium phosphate ceramics having a different chemical composition. Biomaterials 1993; 14: 423429.

29) Rutherford RB, Moalli M, Franceschi RT, Wang D, $\mathrm{Gu}$ K, Krebsbach PH. Bone morphogenetic proteintransduced human fibroblasts convert to osteoblasts and form bone in vivo. Tissue Eng 2002; 8: 441-452.

30) Bancroft GN, Sikavitsas VI, Dolder Jvd, Sheffield TL, Ambrose CG, Jansen JA, Mikos AG. Fluid flow increases mineralized matrix deposition in $3 \mathrm{D}$ perfusion culture of marrow stromal osteoblasts in a dose-dependent manner. Proc Natl Acad Sci USA 2002; 99: 12600-12605.

31) Shin H, Zygourakis K, Farach-Carson MC, Yaszemski MJ, Mikos AG. Modulation of differentiation and mineralization of marrow stromal cells cultured on biomimetic hydrogels modified with ArgGly-Asp containing peptides. J Biomed Mater Res A 2004 69: 535-543. 